\title{
The Effectiveness of Diaphragm Therapy on Physical and Psycho-Spiritual Comfort in COPD Patients in Cempaka Pavilion Room Jombang Hospital
}

\author{
Agustina Maunaturrohmah $^{1}$, Endang Yuswatiningsih ${ }^{1}$ \\ ${ }^{1}$ Nursing Study Program, STIKes Insan Cendekia Medika Jombang \\ Email: agustina.rohmah30@gmail.com
}

Received 1 February 2019; Accepted 1 February 2019; Published 22 May 2019

\begin{abstract}
Chronic Obstructive Pulmonary Disease (COPD) is a chronic infectious disease characterized by air flow resistance in the airways which is progressively non-reversible or partial reversible, this condition can cause patients to experience shortness of breath, giving rise to conditions of discomfort in body functions and patients limitations in carrying out activities daily. The aim of this study was to analyze the effectiveness of diaphragm therapy for the comfort of patients with chronic obstructive pulmonary disease (COPD). This therapy is carried out three times in a week. The design of this study was one group pre-post test. The population in this study were all COPD patients in the Cempaka Pavilion Jombang Hospital treatment room with an average of 26 COPD patients per month. The sample in this study was 20 respondents using simple random sampling technique. Data collection using a questionnaire. Processing data using editing, coding, scoring, tabulating and analyzing data using statistical tests Paired Sample T Test with alpha 0.05. The results showed that before being given diaphragm therapy 13 respondents $(65 \%)$ felt uncomfortable and after being given diaphragm therapy 14 respondents (70\%) felt comfortable. The results of statistical tests with Paired Sample T Test obtained a value of $p=0.035<$ alpha $=0.05$ so that $\mathrm{H} 1$ was accepted.The conclusion in this study is effective diaphragm therapy for comfort in patients with chronic obstructive pulmonary disease (COPD).
\end{abstract}

Keywords: Diaphragm therapy, comfort, COPD

Copyright $\odot 2019$ STIKes Surya Mitra Husada

All right reserved.

This is an open-acces article distributed under the terms of the Creative Commons AttributionShareAlike 4.0 International License.

\section{INTRODUCTION}

Chronic Obstructive Pulmonary Disease (COPD) is a chronic infectious disease characterized by air flow resistance in the airways that is progressively non-reversible or partial reversible. COPD consists of chronic bronchitis and emphysema (Indonesian Doctors Association, 2003). COPD is not a single disease but is a term used to describe chronic lung disease which causes limitations in pulmonary air flow (WHO, 2014). 
United States COPD is the third leading cause of death, and more than 11 million people have been diagnosed with COPD (American Lung Association, 2015). According to research data from the Regional COPD Working Group conducted in 12 countries in the Asia Pacific the average prevalence of COPD is 6.3\%, with the lowest 3.5\% in Hong Kong and Singapore, and the highest in Vietnam as much as $6.7 \%$ in 2002 COPD is the fifth leading cause of death. The highest prevalence of COPD was in east Nusa Tenggara (10.10\%), Central Sulawesi (8.0\%), West Sulawesi and South Sulawesi (6.7\%) (Riskesdas, 2013). The prevalence of asthma, COPD and cancer based on interviews in Indonesia was 4.5 percent, 3.7 percent and 1.4 per mile, respectively (Riskesdas, 2013). Data in the room of the Cempaka Pavilion in Jombang District Hospital for inpatients with chronic obstruction in 2015 amounted to 327 people, in 2016 reached 373 people, while in 2017 from January - February it reached 55 people (RSUDJombang 2017).

Smoking habits are quite high (men over 15 years old 60-70\%), population growth, increasing age average population, industrialization and air pollution (especially in industrial areas) (PDPI, 2003). COPD is a systemic disease involving metabolic, skeletal muscle and genetic molecule. Skeletal muscle dysfunction is the main thing that plays a role in the limited activity of systemic inflammation sufferers (Oemiati, 2013). This will result in the patient's daily activities and physical and psychospiritual comfort. Comfort is a pattern of pleasure, relief and perfection in physical, psycho-spiritual, environmental, and social dimensions (Herdman, T. Heather, 2015-2017). Comfort is the main goal of nursing because the comfort of patient recovery can be obtained (Alligood\&Tomey, 2006).

The diaphragmatic breathing exercise aims to allow patients with ventilatory problems to achieve more optimal, controlled, efficient ventilation and reduce breathing work. Respiratory training in patients with chronic obstructive pulmonary disease is intended to improve the function of the respiratory equipment, with the aim of being able to train patients to regulate breathing. The advantage of diaphragmatic breathing exercises is that it optimizes the use of the diaphragm muscle and strengthens the diaphragm during breathing (Muttaqin, 2008). Using the technique consists of 2-4 -2, namely: two seconds with inhalation, followed by four seconds holding the breath by allowing the abdominal muscles to stand as big as possible, and two seconds inhalation or exhaling with a frequency of 3 times a week lasting $\leq$ 5-10 minutes Nugroho S, 2011).

The aim of this study was to determine the effect of diaphragm therapy on comfort in patients with chronic obstructive pulmonary disease (COPD).

\section{MATERIALS AND METHODS}

This type of pre-experimental research is a research design used to find a causal relationship with the involvement of research in manipulating independent variables (Nursalam, 2014). The research design used was Posttest Only, Non-Equivalent Control Group Design, namely there was an experimental group and there was a control group. This design subjects were placed randomly into groups and exposed as independent variables were given a post test. Post-test values are then compared to determine the effectiveness of treatment.This design is the simplest design of the actual experimental design (true experimental design), because the respondents were actually randomly selected and treated and there was a group of controllers. This design has met the actual experimental criteria, namely by the presence of variable manipulation, random selection of groups studied and treatment selection.

In the experimental group subjected to treatment X1 and in the control group were not treated. And at the end of the study both groups were subjected to posttest. The choice of subjects in the two groups subjected to the experiment did not use the randomization process, but instead used existing groups.Randomization is a prerequisite for experimental research and 
aims to have comparability (internal validity) between the same study group and controls. Randomization is not the same as random sampling.

The population used was all patients with chronic obstructive pulmonary disease in the Cempaka Room of Jombang District Hospital at the last 3 months from December to February with an average of 26 people / month. The sample in this study is that some patients with chronic obstructive pulmonary disease in the Cempaka Pavilion Room in Jombang District Hospital for the experimental group amounted to 20 respondents and 25 for the control group using simple random sampling. In this technique each individual has the same opportunity or opportunity to be used as the subject of research. It can be said, random sampling is a procedure that allows each element in the population to have the same opportunity to be used as a sample.

Data collection for comfort level was measured by the General comfort questionnairewith the number of statements 48 using the Likert scale 1,2,3,4, with the highest score marking the high level of comfort, 24 statements from 2 parameters were taken, namely physical and psychospiritual comfort which were positive statements and negative statements. Univariate analysis using $\mathrm{T}$ scores while bivariate analysis because to determine the effectiveness of using interval data scales then use the Independent Sample T Test analysis test with an error rate of $5 \%$.

\section{RESULTS}

a. Intervention group

1. Characteristics of respondents based on age

Table 1 Frequency distribution of respondents based on age in the Jombang District Hospital pavilion in 2018.

\begin{tabular}{cccc}
\hline No & Age & Frequency & Percentage $(\%)$ \\
\hline 1 & 20-30 years & 1 & 5 \\
2 & 31-40 years & 2 & 10 \\
3 & 41-50 years & 6 & 30 \\
4 & 51-60 years & 11 & 55 \\
\hline & Total & 20 & 100 \\
\hline
\end{tabular}

Source: 2018 primary data

Table 1 shows that out of 20 respondents most of the respondents were 51-60 years old with 11 people (55\%). 
b. Comfort of patients with chronic obstructive pulmonary disease in the intervention group

Table 6 Frequency distribution of respondents based on the convenience of patients with chronic obstructive pulmonary disease in the intervention group in the Cempaka Pavilion of Jombang District Hospital in 2018.

\begin{tabular}{cccc}
\hline No & Convenience & Frequency & Percentage (\%) \\
\hline 1 & Comfortable & 17 & 85 \\
2 & Uncomfortable & 3 & 15 \\
\hline & Total & 20 & 100 \\
\hline
\end{tabular}

Source: 2018 primary data

Table 6 shows that out of 20 respondents almost all respondents experienced a comfortable number of 17 respondents $(85 \%)$.

c. Control group

1. Characteristics of respondents based on age

Table 1 Frequency distribution of respondents based on age in the Jombang District Hospital pavilion in 2018.

\begin{tabular}{cccc}
\hline No & Age & Frequency & Percentage (\%) \\
\hline 1 & 20-30 years & 3 & 12 \\
2 & 31-40 years & 4 & 16 \\
3 & 41-50 years & 6 & 24 \\
4 & 51-60 years & 12 & 48 \\
\hline & Total & 25 & 100 \\
\hline
\end{tabular}

Source: 2018 primary data

Table 1 shows that of the 25 respondents almost half of the respondents were 51-60 years old with 12 people (48\%).

2. Comfort of patients with chronic obstructive pulmonary disease in the control group

Table 6 Frequency distribution of respondents based on the convenience of patients with chronic obstructive pulmonary disease in the control group in the Cempaka Pavilion of Jombang District Hospital in 2018.

\begin{tabular}{cccc}
\hline No & Post test & Frequency & Percentage (\%) \\
\hline 1 & Comfortable & 11 & 44 \\
2 & Uncomfortable & 14 & 56 \\
\hline Total & 25 & 100 \\
\hline
\end{tabular}

Source: 2018 primary data

Table 6 shows that of the 25 respondents most of them experienced discomfort with the number of 14 respondents $(56 \%)$. 
3. Results of measurement of comfort in patients with chronic obstructive pulmonary disease in the intervention group

Table 7 Results of measurement of comfort in patients with chronic obstructive pulmonary disease in the Cempaka Pavilion in Jombang District Hospital in 2018.

\begin{tabular}{ccccc}
\hline Comfort of COPD patients & $\begin{array}{c}\text { Intervention } \\
\text { group }\end{array}$ & $\begin{array}{c}\text { Percentage } \\
(\mathbf{\%})\end{array}$ & $\begin{array}{c}\text { Control } \\
\text { group }\end{array}$ & $\begin{array}{c}\text { Percentage } \\
(\boldsymbol{\%}\end{array}$ \\
\hline Comfortable & 17 & 85 & ) 11 & 44 \\
\hline Uncomfortable & 3 & 15 & 14 & 56 \\
\hline Total & 20 & 100 & 25 & 100 \\
\hline Test independent sample t test $p$ value $=0,026$ & & & \\
\hline
\end{tabular}

Source: 2018 primary data

Table 7 shows that of the 20 respondents with chronic obstructive pulmonary disease in the intervention group, almost all respondents felt comfortable with 17 respondents (85\%), while from 25 respondents chronic obstructive pulmonary disease in the control group most respondents felt uncomfortable with the number of 14 respondents ( 56\%).

The statistical test results of the independent sample $t$ test obtained significant numbers or probability values $=0,026$ less than the alpha value of 0.05 or $(p<\alpha)$ because $(p<\alpha)$, meaning $\mathrm{H} 1$ is accepted, the conclusion is effective diaphragmatic breathing therapy chronic obstructive pulmonary disease (COPD) based on the theory of comfort in the Cempaka Pavilion Hospital in Jombang Regency.

\section{DISCUSSION}

1. Interventional diaphragmatic breathing group therapy

The data from the study found that most of the intervention group respondents were 5160 years old with 11 people or 55\%. The researcher argues that this is because those aged 5160 years are an advanced age group, at this age there will be a decrease in organ function with the nature of COPD which is progressive and nonversible. In accordance with the theory of Kolcaba (2003), it is explained that age can affect one's perception of total comfort. Age can also affect normal physical characteristics. The ability to participate in preoperative physical examinations is also influenced by age (Asmadi, 2008).

Data from the research also showed that most respondents smoke 12 respondents $(60 \%)$. The smoking behavior of the respondents has begun to be teenagers, almost all of the cigarettes spent in a day $\geq 4$ with a total of 14 respondents (93.3\%). Smoking is the most important causal cause of other factors. Substances contained in cigarettes can cause damage to lung tissue resulting in narrowing of the airways, so that patients feel tight. Such conditions will interfere with the patient's activities so that discomfort arises. In accordance with the theory of skeletal muscle dysfunction is the main thing that plays a role in the limited activity of patients with systemic inflammation, increased risk of cardiovascular disease, osteoporosis, and depression is a systemic manifestation of chronic obstructive pulmonary disease (Oemiati, 2013).

Table 6a states that almost all respondents in the intervention group experienced physical comfort after diaphragmatic breathing therapy with 17 respondents (85\%). The highest physical comfort value in question 9 about "I feel strong enough to walk" with an average parameter value of 3.7. Researchers argue that diaphragmatic breathing exercises can 
improve respiratory function so that patients can regulate breathing, so that clients can carry out activities especially in walking. In accordance with the theory of Muttaqinarrif (2009) explaining the purpose of respiratory diaphragm is the implementation of optimizing the use of the diaphragm muscle and strengthening the diaphragm during breathing. Diaphragmatic breathing exercises are carried out with the aim that patients with ventilation problems can achieve more optimal ventilation, control, efficiency, and can reduce respiratory work. Breathing exercises are carried out by relaxing the upper chest, arms and shoulders.

The highest psychospiritual comfort value in question number 13 about "I still patiently face pain" with a parameter average value of 4.45. After doing the therapeutic exercise the client can make breathing arrangements better, namely from breathing which is fast and shallow to become slower and deeper so the client can relax. In accordance with Kolbaca's theory, 2011 states that psychospiritual comfort is obtained when patients are free from anxiety, fear, and anxiety.

\section{Comfort of COPD patients after diaphragmatic breathing therapy}

Data from the study found that almost half of the respondents in the intervention group were 51-60 years old with 12 people or 48\%. Elderly with a age range of 51-60 there are some changes from the physical and bodily functions of the body. In accordance with the theory of Kolcaba (2003), it is explained that age can affect one's perception of total comfort. Age can also affect normal physical characteristics. The ability to participate in preoperative physical examinations is also influenced by age (Asmadi, 2008).

Data from the study also showed that most never knew about diaphragmatic breathing exercises with a total of 17 respondents $(68 \%)$. The researcher argues that with no exposure to the patient with information about the diaphragm, the patient cannot know the benefits and how to do the breathing exercises. One of the benefits of diaphragmatic breathing exercises is to regulate the balance of bodily functions, improve movement and inner calmness in accordance with the theory of Nugroho S (2011).

Table $6 \mathrm{~b}$ states that most respondents experienced discomfort with the number of 14 respondents (56\%). The lowest physical comfort value in questions 1 and 2 about "I still do not want to exercise", "I feel unwell" with an average value of 2.8. The purpose of diaphragmatic breathing is to optimize the use of the diaphragm muscle and strengthen the diaphragm during breathing (Muttaqinarif, 2009).

The lowest psychospiritual comfort value in question 6 about "I am afraid of what happens next". The researcher argues that with no reduction in the symptoms of COPD, the respondent will feel anxious about the next situation. This situation can cause discomfort to the respondent. In accordance with the theory which states that diaphragmatic breathing exercises can relieve mild anxiety and indifference to the disease being suffered (Nugroho S, 2011)

\section{The effectiveness of diaphragm therapy for comfort in COPD patients}

The statistical results of the independent sample $t$ test obtained significant numbers or probability values $=0,026$ less than the alpha value of 0.05 or $(p<\alpha)$, because $(p<\alpha)$, meaning $\mathrm{H} 1$ is accepted, the conclusion is more effective diaphragmatic breathing therapy given to patients with chronic obstructive pulmonary disease (COPD) based on the theory of comfort in the Cempaka Pavilion Hospital in Jombang Regency.

Effective diaphragmatic respiration of the physical and psychospiritual comfort of COPD patients, this is evidenced by the differences in respondents in the intervention group (given diaphragmatic respiration) with control respondents (who were not given diaphragmatic breathing). The diaphragmatic breathing exercise given to the respondent is an easy exercise, 
carried out in a slow, conscious, and not compelling manner. Diaphragmatic breathing exercises performed routinely for 3 days caused the respondents to experience physical and mental changes. With the respiration of the diaphragm the respondent's muscles will become loose and relaxed so that the patient makes the mind calm the patient can feel physical comfort and can reduce the tightness complained by the patient.

\section{CONCLUSION}

Respiratory exercises can be used as a reference for non-pharmacological actions. The respiratory technique used is diaphragmatic breathing. Breathing exercises are carried out by relaxing the upper chest, arms and shoulders (Nurun S, 2014). Respiratory exercise in patients with chronic obstructive pulmonary disease is intended to improve the function of the respiratory tract, with the aim of being able to train patients to regulate breathing. The advantage of diaphragmatic breathing exercises is that it optimizes the use of the diaphragm muscle and strengthens the diaphragm during breathing (Muttaqin, 2008).

\section{REFERENCE}

Alligood, Mr., \& Tomey, AM. (2006). Nursing Theories and their work, $7^{\text {th }}$ edn, Mosby Elsevier, Louist, missori.

American Lung Association. $\quad$ (2015). Pneumonia.
http://www.lung.org/lungdisease/pneumonia/understandingpneumonia.html.

Asmadi. (2008). Konsep Dasar Keperawatan. Jakarta: EGC.

Departemen Kesehatan RI. (2008). Pedoman Pengendalian Penyakit Paru Obstruktif. Jakarta.

Herdman, T. Heather, \& Internasional, N. (2015-2017). Diagnosis keperawatan. Buku Kedokteran EGC, Jakarta, Salemba Medika. Jakarta.

Muttaqin, \& Arif. (2008). Buku ajar, Asuhan keperawatan klien dengan gangguan sistem pernafasaan.

Nugroho, S. (2011). Terapi Pernafasaan Pada Penderita Asma. Pendidikan Kesehatan Falkutas Ilmu Keolahragaan Universitas Negeri Yogyakarta.

Nursalam. (2013). Metode Penelitian Ilmu Keperawatan Pendekatan Praktis, Edisi 3. Jakarta. Salemba Medika.

Nurun, S. Purba, A. \& Defi, I. (2014). Efektifitas latihan incentive spirometry dengan latihan pernafasaan difragma terhadap fungsi paru, kapasitas, fungsional dan kualitas hidup penderita asma.

Oemiati, R. (2013). Kajian Epidemologis Penyakit Paru Obstruktif Kronik; jurnal media litbangkes. Vol.23 no. 2 juni hal $82-88$.

Riset Kesehatan Dasar. (2013). Pedoman Pewawancara Petugas Pengumpul Data. Badan Litbangkes: Jakarta.

Sugiarti, \& Sondari. (2015). Gambaran Penyakit Paru Obstruktif Kronik didaerah pertambangan, kabupaten muara enim, Sumatra Selatan.

WHO. (2010). Penyakit Paru Obstruktif Kronik. (Diakses pada tanggal 19/02/2017) $<$ http://eprints.unidip.ac.id/12801>, pukul 16.30 .

WHO. (2014). Burden of COPD. Rilis Berita [serial online] 2014. URL: HYPERLINK http://www.who.int/ respiratory/copd/burden/en. 